\title{
Pengaruh Profesionalisme, Independensi dan Pelatihan Auditor Terhadap Kinerja Auditor Pada Kantor Akuntan Publik Provinsi Bali
}

\author{
Ni Putu Haris Candra Devi ${ }^{1}$ \\ I Made Pande Dwiana Putra ${ }^{2}$
}

\author{
${ }^{1,2}$ Fakultas Ekonomi dan Bisnis Universitas Udayana (Unud), Bali, Indonesia \\ e-mail: niputuhariscandradevi@yahoo.com
}

\begin{abstract}
ABSTRAK
Tujuan dari penelitian ini adalah untuk mendapatkan bukti empiris pengaruh profesionalisme, Independensi dan Pelatihan Auditor terhadap kinerja auditor. Lokasi dari penelitian ini adalah pada Kantor Akuntan Publik (KAP) yang berada di Provinsi Bali tahun 2018 dan telah terdaftar dalam Ikatan Akuntan Publik Indonesia (IAPI). Metode penentuan sampel yang digunakan dalam penelitian ini adalah metode sampel jenuh. Metode pengumpulan data dalam penelitian ini adalah metode angket. Teknik analisis data yang digunakan dalam penelitian ini adalah analisis regresi linear berganda. Berdasarkan hasil analisis regresi linear berganda menunjukkan bahwa profesionalisme, independensi dan pelatihan auditor berpengaruh positif terhadap kinerja auditor. Penelitian ini diharapkan dapat memberikan informasi serta pemahaman lebih mendalam, dan diharapkan auditor dapat menjunjung tingga profesionalisme dan independensi saat melakukan audit, sehingga kinerja auditor tersebut akan baik.
\end{abstract}

Kata kunci: Profesionalisme, independensi, pelatihan auditor, kinerja auditor

\begin{abstract}
The purpose of this study is to obtain empirical evidence of the influence of professionalism, independence and auditor training on auditor performance. The location of this research is at the Public Accountant Office (KAP) in Bali Province in 2018 and has been registered with the Indonesian Institute of Certified Public Accountants (IAPI). The method of determining the sample used in this study is the saturated sample method. The method of data collection in this study is the questionnaire method. The data analysis technique used in this study is multiple linear regression analysis. Based on the results of multiple linear regression analysis shows that professionalism, independence and auditor training have a positive effect on auditor performance. This research is expected to provide more in-depth information and understanding, and it is hoped that the auditor can uphold the professionalism and independence when conducting audits, so that the auditor's performance will be good.
\end{abstract}

Keywords: Professionalism, independence, auditor training, auditor performance

\section{PENDAHULUAN}

Kasus KAP Arthur Andersen dengan Enron yang melakukan kecurangan yaitu memanipulasi laporan keuangan merupakan salah satu yang membuat kinerja auditor menjadi perhatian utama, baik bagi klien ataupun publik saat ini. Keberadaan auditor juga tidak terlepas dari adanya kebutuhan manajemen akan 
Ni Putu Haris Candra Devi dan I Made Pande Dwiana Putra. Pengaruh ...

transparasi dan pertanggungjawaban atas kinerja perusahaan. Seorang auditor harus mampu berperan menjadi mediator bagi perbedaan-perbedaan kepentingan antar berbagai pelaku bisnis dan masyarakat. Agar mampu menjalankan peran tersebut, auditor harus selalu menjaga mutu jasa yang diberikannya dan menjaga independensi, integritas, dan objektivitas profesinya.

Perkembangan auditor di Indonesia masih belum baik. Ikatan Akuntan Indonesia menyatakan bahwa jumlah auditor di Indonesia berkisar 20.000 orang, sedangkan itu tidak sebanding dengan jumlah perusahaan yang menyusun laporan keuangan yang berkisar 3 juta perusahaan. Beberapa kasus juga belum dapat diselesaikan oleh auditor di Indonesia terkait penyelewengan atau kecurangan pada laporan keuangan. Perkembangan auditor di Bali juga masih belum baik, KAP yang ada di Bali sampai tahun 2018 ini ada 9 KAP. Bali terkenal dengan daerah pariwisatanya, hotel merupakan salah satu perusahaan yang paling banyak di Bali. Tahun 2018 tercatat sekitar 2000an hotel yang ada di Bali. Jika semua hotel tersebut menyusun laporan keuangan, 9 KAP tidak sebanding dengan jumlah hotel yang ada di Bali.

Pentingnya peran profesi akuntan publik serta beragamnya pengguna jasa, menyebabkan jasa profesi akuntan publik harus dapat dipertanggungjawabkan kepada pihak-pihak yang berkepentingan tersebut. Baik atau tidaknya pertanggungjawaban yang diberikan tergantung dari kinerja auditor. Kinerja auditor adalah kemampuan dari seorang auditor menghasilkan temuan atau hasil pemeriksaan dari kegiatan pemeriksaan atas pengelolaan dan tanggung jawab keuangan yang dilakukan dalam satu tim pemeriksaan (Yanhari, 2007). 
Kompetensi seorang auditor tidak hanya dilihat dari segi teknis tapi juga dari segi etika (Cathy dan Christine, 2011).

Kinerja auditor dalam memberikan jasa akuntan publik dipengaruhi oleh beberapa faktor, seorang yang memiliki profesionalisme dapat dipercaya dan diandalkan dalam melaksanakan pekerjaannya sehingga dapat berjalan lancar, baik dan mendatangkan hasil yang diharapkan. Untuk menghasilkan laporan audit yang baik dan berkualitas sehingga terciptanya kepercayaan pada pengguna informasi laporan keuangan, maka diperlukan sikap independen dari auditor agar laporan audit tersebut dapat dipercaya dan diandalkan. Pelatihan mengenai audit dengan intensitas yang lebih sering akan meningkatkan kemampuan auditor dalam mendeteksi kecurangan. Dari ketiga hal tersebut, profesionalisme, independensi dan pelatihan auditor dapat ditinjau lebih lanjut bagaimana pengaruhnya terhadap kinerja auditor.

Auditor dengan pandangan profesionalisme yang tinggi akan memberikan pengaruh positif bagi kinerjanya, sehingga hasil audit laporan keuangan akan lebih dapat dipercaya oleh para pengambil keputusan baik pihak internal ataupun eksternal perusahaan. Dalam menjalankan profesinya akuntan publik juga dituntut untuk memiliki prinsip dan moral, serta perilaku etis yang sesuai dengan etika. Memahami peran perilaku etis seorang auditor dapat memiliki efek yang luas pada bagaimana bersikap terhadap klien mereka agar dapat bersikap sesuai dengan aturan akuntansi berlaku umum (Curtis et al., 2012).

Profesionalisme seorang auditor harus berpedoman pada standar audit yang telah ditetapkan oleh Institut Akuntan Publik Indonesia (IAPI), yang menyatakan 
Ni Putu Haris Candra Devi dan I Made Pande Dwiana Putra. Pengaruh ...

bahwa profesional yang dimaksud adalah praktisi (auditor) harus bersikap dan bertindak secara hati-hati, menyeluruh, dan tepat waktu, sesuai dengan persyaratan penugasan. Jika auditor tidak seperti itu, maka dianggap tidak profesional atau tidak memiliki sikap profesionalisme. Menurut penelitian Bamber dan Iyer (2002), Cohen dan Single (2001), Dinata (2013) dan Adhi (2015) menyatakan bahwa profesionalisme berpengaruh positif terhadap kinerja auditor, yang dimana semakin tinggi tingkat keprofesionalismean auditor maka kinerja yang dihasilkan akan semakin memuaskan.

Independensi memiliki arti bahwa seorang akuntan publik harus jujur tidak hanya terhadap manajemen dan pemilik perusahaan, tetapi terhadap kreditur dan pihak lain yang dimana mereka meletakkan keyakinan pekerjaan mereka pada akuntan publik. Bagi akuntan publik keharusan memelihara atau mempertahankan sikap mental yang independen dalam rangka memenuhi tanggungjawab profesionalnya bukanlah satu-satunya hal yang esensial akan tetapi kepercayaan para pemakai laporan keuangan terhadap independensi akuntan publik juga merupakan hal yang sangat penting (Winarna, 2005). Hal ini sesuai dengan penelitan yang dilakukan Gabritha (2014) menyatakan bahwa Independensi berpengaruh signifikan terhadap kinerja auditor pada Kantor Akuntan Publik di Jakarta dan Dinata (2013) dalam penelitiannya di Kantor Akuntan Publik di Bali menyatakan bahwa indepensensi berpengaruh positif terhadap kinerja auditor.

Dalam rangka memenuhi persyaratan sebagai seorang profesional, auditor harus menjalani pelatihan yang cukup. Pelatihan dapat dilakukan dengan mengikuti seminar atau simposium. Bertambahnya pengalaman auditor yang 
diperoleh melalui pelatihan akan meningkatkan ketelitian dalam melakukan pemeriksaan. Pemeriksaan yang dilakukan dengan ketelitian yang tinggi menghasilkan laporan audit yang berkualitas dan menunjukkan kinerja auditor yang baik. Jamilah (2008) dan Adinda (2014) menunjukkan bahwa variabel pelatihan auditor berpengaruh secara signifikan terhadap kinerja auditor junior, serta penelitian yang dilakukan oleh Adhi (2015) yang menyatakan pelatihan auditor berpengaruh positif terhadap kinerja auditor.

Fenomena-fenomena kasus suap yang terjadi pada auditor akhir-akhir ini membuat independensi seorang auditor dipertanyakan kembali oleh masyarakat. Kasus pelanggaran sikap independensi yang dilakukan akuntan publik Justinus Aditya Sidharta, dimana ia melakukan kesalahan dalam mengaudit laporan keuangan PT. Great River Internasional, Tbk memunculkan suatu paradigma dimana masalah tersebut memang tidak mampu dibaca oleh akuntan publik yang mengaudit laporan keuangan tersebut atau sebenarnya telah terbaca oleh auditor tersebut namun auditor tersebut sengaja memanipulasinya. Apabila kenyataan akuntan publik ikut memanipulasi laporan keuangan tersebut, maka independensi auditor tersebut patut dipertanyakan kembali (Adhi, 2015).

Kasus yang terjadi pada auditor di BUMN dimana komisaris PT. Kereta Api mengungkapkan adanya suatu kebohongan atau manipulasi laporan keuangan BUMN tersebut dimana seharusnya perusahaan menerima kerugian tetapi auditor melaporkan menerima keuntungan. Dari dua kasus tersebut dapat kita simpulkan, bahwa seorang akuntan publik sudah seharusnya menaati dan memegang secara teguh Standar Profesional Akuntan Publik (SPAP). Apabila seorang auditor tidak 
Ni Putu Haris Candra Devi dan I Made Pande Dwiana Putra. Pengaruh ...

dapat menjalankan tugasnya sesuai dengan etika maka izin yang dimiliki auditor tersebut akan dicabut seperti yang terjadi terhadap Akuntan Publik Justinus Aditya Sidharta yang jelas-jelas telah melakukan pelanggaran terhadap SPAP berkaitan dengan Laporan Audit atas Laporan Keuangan Konsolidasi dimana hal ini akan merusak nama baik dari akuntan publik tersebut dan kepercayaaan masyarakat terhadap akuntan publik tersebut tentu akan rusak.

Berdasarkan hal tersebut, maka tujuan penelitian untuk mendapatkan bukti empiris pengaruh profesionalisme, independensi dan pelatihan auditor terhadap kinerja auditor. Selanjutnya berdasarkan tujuan penelitian, kajian-kajian teori relevan dan hasil-hasil penelitian sebelumnya, maka maka dapat dirumuskan hipotesis sebagai berikut:

$\mathrm{H}_{1}$ : Profesionalisme berpengaruh positif terhadap kinerja auditor.

$\mathrm{H}_{2}$ : Independensi berpengaruh positif terhadap kinerja auditor.

$\mathrm{H}_{3}$ : Pelatihan auditor berpengaruh positif terhadap kinerja auditor.

\section{METODE PENELITIAN}

Berdasarkan tujuan dan hipotensis penelitian yang sudah dipaparkan, maka desain dari penelitian ini dapat dilihat pada Gambar 1 berikut.

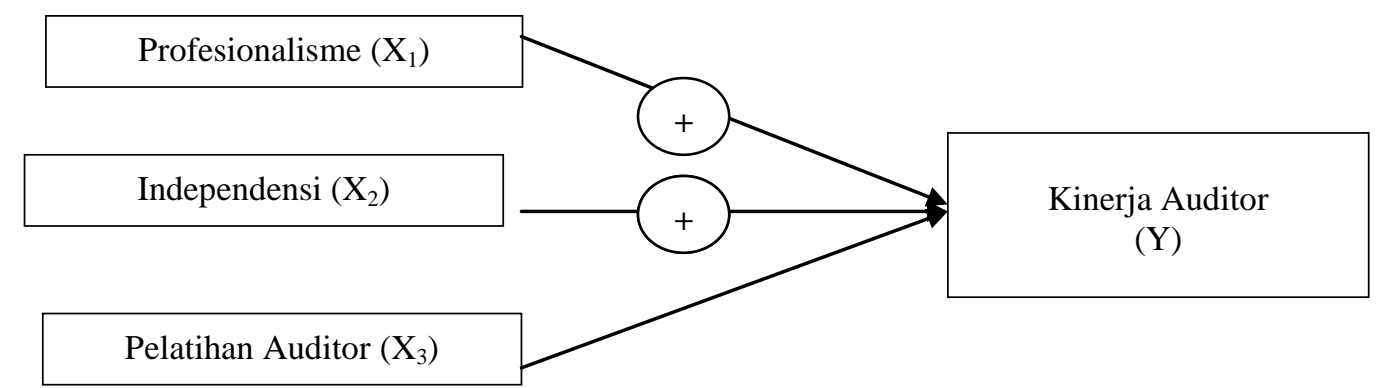

Gambar 1. Desain Penelitian

Sumber : Data diolah, 2018 
Lokasi dari penelitian ini adalah pada Kantor Akuntan Publik (KAP) yang berada di Provinsi Bali tahun 2018 dan telah terdaftar dalam Institut Akuntan Publik Indonesia (IAPI). Lokasi tersebut dipilih untuk memudahkan pengumpulan data karena kantor akuntan publik yang terdaftar dalam Direktori akan mudah diketahui nama beserta alamatnya. Kantor akuntan publik yang terdaftar di Direktori telah memperoleh ijin dari Menteri keuangan Republik Indonesia sebagai wadah dari akuntan publik dalam melaksanakan pekerjaannya. Berikut daftar Kantor Akuntan Publik (KAP) di Bali Tahun 2018.

Objek dari penelitian ini adalah pada Kantor Akuntan Publik di Provinsi Bali mempengaruhi profesionalisme, independensi dan pelatihan auditor terhadap kinerja auditor. Kepercayaan pengguna informasi terhadap kinerja dalam kualitas jasa akuntan publik akan semakin tinggi apabila profesi tersebut dilaksanakan dengan profesional. Auditor memiliki independensi, prinsip etika profesi, memiliki tanggung jawab yang tinggi dalam melaksanakan pekerjaannya sehingga meningkatkan kinerjanya sebagai auditor. Auditor dengan pelatihan yang cukup akan lebih cepat tangkap dalam memprediksikan kekeliruan yang terjadi sehingga dapat meningkatkan ketelitian dalam melakukan pemeriksaan.

Identifikasi variabel dalam penelitian ini dibagi menjadi 2 yaitu variabel independen dan variabel dependen. Variabel independen dalam penelitian ini meliputi profesionalisme $\left(\mathrm{X}_{1}\right)$, independensi $\left(\mathrm{X}_{2}\right)$, dan pelatihan auditor $\left(\mathrm{X}_{3}\right)$. Sedangkan, variabel dependen dalam penelitian ini meliputi kinerja auditor (Y).

Profesionalisme adalah suatu atribut individual yang penting tanpa melihat suatu pekerjaan merupakan suatu profesi atau tidak. Jadi dapat dikatakan bahwa 
Ni Putu Haris Candra Devi dan I Made Pande Dwiana Putra. Pengaruh ...

profesionalisme itu adalah sikap tanggungjawab dari seorang auditor dalam menyelesaikan pekerjaan auditnya dengan keikhlasan hatinya sebagai seorang auditor. Indikator dalam penelitian ini meliputi pengabdian pada profesi, kewajiban sosial, kemandirian, keyakinan terhadap peraturan profesi, dan hubungan dengan sesama profesi.

Independensi merupakan dasar utama kepercayaan masyarakat pada profesi akuntan publik dan merupakan salah satu faktor yang sangat penting untuk menilai mutu jasa audit. Indikator dalam penelitian ini meliputi independensi sikap mental, independensi penampilan, independensi praktisi dan independensi profesi.

Kurikulum yang ada tidak cukup untuk membangun kesuksesan akuntan, untuk itu diperlukan peltihan melalui kursus-kursus pendidikan profesional lanjutan. Indikator-indikator dari pelatihan ini dimodifikasi dengan mengurangi jumlah pernyataan karena beberapa pertanyaan dianggap tidak dapat menjelaskan variabel yang baik. Indikator dalam penelitian ini meliputi mengikuti pelatihan pajak, mengikuti pelatihan perbankan, pelatihan sesuai dengan tingkatan indikator, mengukuti seminar/simposium dan memperbaiki prestasi kerja (Noviyani dan Bandi, 2002)

Kinerja auditor (Y), pengertian kinerja (prestasi kerja) adalah hasil kerja secra kualitas dan kuaantitas yang dicapai oleh seseorang pegaawai dalam melaksanakan tugasnya sesuai dengan tanggung jawab yang diberikan kepadanya. Variabel kinerja auditor dalam penelitian ini diukur dengan instrumen yang digunakan Chandra (2006), Bahri (2010), Cholifah (2010), Dinata (2013) yang 
telah memodifikasi dengan indikator yaitu patuh terhadap prosedur audit, mampu menyelesaikan tugas dengan baik dan tepat waktu, mengutamakan kerja sama dengan rekan kerja, mampu mengkomunikasikan hasil audit dan mendahulukan daripada kuantitas.

Populasi dalam penelitian ini adalah seluruh auditor yang bekerja pada Kantor akuntan publik di Bali. Kantor Akuntan Publik yang digunakan adalah yang terdaftar dalam Direktori yang diterbitkan oleh Institut Akuntan Publik Indonesia tahun 2017 yang berlokasi di Bali. Metode penentuan sampel yang digunakan dalam penelitian ini adalah metode sampel jenuh. Metode sampel jenuh adalah teknik penentuan sampel bila semua anggota populasi digunakan menjadi sampel. Adapun nama KAP, jumlah auditor pada masing-masing KAP dan jumlah auditor yang memenuhi syarat menjadi sampel tahun 2018 yang disajikan pada Tabel 1 berikut.

Tabel 1.

Jumlah Auditor pada Masing-Masing KAP di Bali Tahun 2018

\begin{tabular}{clc}
\hline No & \multicolumn{1}{c}{ Nama Kantor Akuntan Publik } & Jumlah Auditor pada KAP \\
\hline 1. & KAP Drs. Ketut Budiartha, Msi & 6 \\
2. & KAP I Wayan Ramantha & 9 \\
3. & KAP Drs. Ketut Muliartha R.M. \& Rekan & 10 \\
4. & KAP Drs. Sri Marmo Djogosarkoso \& Rekan & 16 \\
5. & KAP Drs. Wayan Sunasdyana & 7 \\
6. & KAP Drs. Johan, Molanda, Astika \& Rekan (Cab) & 8 \\
7. & KAP K. Gunarsa & 3 \\
8. & KAP Anaya \& Darmayasa & 8 \\
9. & KAP Budhananda Munidewi & 8 \\
& Total & 75 \\
\hline
\end{tabular}

Sumber: Data diolah, 2018

Metode pengumpulan data dalam penelitian ini adalah metode angket, yaitu menyebarkan daftar pertanyaan (kuesioner) yang akan diisi atau dijawab oleh responden auditor pada KAP di Provinsi Bali dan terdaftar pada IAPI. Jawaban 
Ni Putu Haris Candra Devi dan I Made Pande Dwiana Putra. Pengaruh ...

pernyataan responden tersebut diukur dengan menggunakan skala Likert, yaitu pilihan jawaban responden diberi nilai dengan skala 5 poin.

Data instrumen penelitian yang sudah terkumpul dan sudah di rekapitulasi selanjutnya di uji validasi untuk mengukur sah atau valid tidaknya suatu kuesioner, dan untuk mengukur kehandalan jawaban responden menggunakan uji reliabilitas. Apabila data sudah dinyatakan layak dan sudah lolos uji validitas dan reliabiltas, maka selanjutnya dilakukan uji asumsi klasik karena model regresi yang baik adalah model regresi yang terbebas dari masalah normalitas data, multikolinieritas, dan heteroskedastisitas.

Uji hipotesis melalui analis regresi linear berganda (multiple), adalah untuk mengetahui pengaruh Profesionalisme $\left(\mathrm{X}_{1}\right)$, Independensi $\left(\mathrm{X}_{2}\right)$ dan Pelatihan Auditor $\left(\mathrm{X}_{3}\right)$ terhadap Kinerja Auditor $(\mathrm{Y})$. Model regresi linear ganda yang digunakan adalah dengan menggunakan rumus:

$\mathrm{Y}=\alpha+\beta_{1} \mathrm{X}_{1}+\beta_{2} \mathrm{X}_{2}+\beta_{3} \mathrm{X}_{3}+\mathrm{e}$

Notasi:

$$
\begin{array}{ll}
\mathrm{Y} & =\text { Kinerja auditor } \\
\alpha & =\text { Konstanta } \\
\beta_{1,} \beta_{2,} \beta_{3} & =\text { Koefisien regresi } \\
\mathrm{X}_{1} & =\text { Profesionalisme } \\
\mathrm{X}_{2} & =\text { Independensi } \\
\mathrm{X}_{3} & =\text { Pelatihan Auditor } \\
\mathrm{e} & =\text { Komponen pengganggu (error) }
\end{array}
$$

\section{HASIL DAN PEMBAHASAN}

Pengumpulan data dalam penelitian ini menggunakan kuesioner. Total kuesioner yang disebar adalah sebanyak 75 kuesioner di 9 KAP di Provinsi Bali sesuai dengan tabel 3.2 pada Bab III. Sebanyak 75 kuesioner yang disebar, kuesioner 
yang diisi hanya sebanyak 67 kuesioner, sedangkan sebanyak 8 kuesioner tidak terisi (kosong). Tabel 2 merupakan rincian kuesioner yang disebar dan terisi dari 9 KAP yang ada.

Tabel 2.

Rincian Kuesioner Yang Disebar

\begin{tabular}{llccc}
\hline No & \multicolumn{1}{c}{ Nama Kantor Akuntan Publik } & $\begin{array}{c}\text { Jumlah } \\
\text { Kuesioner } \\
\text { Yang } \\
\text { Disebar }\end{array}$ & $\begin{array}{c}\text { Jumlah } \\
\text { Kuesioner } \\
\text { Yang Terisi }\end{array}$ & $\begin{array}{c}\text { Kuesioner } \\
\text { Kosong }\end{array}$ \\
\hline 1. & KAP Drs. Ketut Budiartha, Msi & 6 & 6 & 0 \\
2. & KAP I Wayan Ramantha & 9 & 9 & 0 \\
3. & KAP Drs. Ketut Muliartha R.M. \& Rekan & 10 & 10 & 0 \\
4. & KAP Drs. Sri Marmo Djgosarkoso \& Rekan & 16 & 8 & 8 \\
5. & KAP Drs. Wayan Sunasdyana & 7 & 7 & 0 \\
6. & KAP Drs. Johan, Molanda, Astika \& Rekan (Cab) & 8 & 8 & 0 \\
7. & KAP K. Gunarsa & 3 & 3 & 0 \\
8. & KAP Anaya \& Darmayasa & 8 & 8 & 0 \\
9. & KAP Budhanda Munidewi & 8 & 8 & 0 \\
& Total & 75 & 67 & 8 \\
\hline
\end{tabular}

Sumber: Data diolah, 2018

Karakteristik responden dalam penelitian ini akan menggambarkan profil dari 67 responden yang berpartisipasi dalam pengisian kuesioner. Data profil responden dapat dilihat pada Tabel 3 sebagai berikut.

Tabel 3.

Karakteristik Responden

\begin{tabular}{cccc}
\hline \multirow{2}{*}{ No. } & Karakteristik Responden & \multicolumn{2}{c}{ Jumlah } \\
\cline { 3 - 4 } & Jenis Kelamin & (orang) & Presentase (\%) \\
Pria & Wanita & 37 & 55 \\
Total & 30 & 45 \\
2 & Pendidikan Terakhir & 67 & 100 \\
S3 & & 3 \\
S2 & 2 & 15 \\
S1 & 10 & 67 \\
D3 & 45 & 15 \\
D1 & 10 & 0 \\
SMA & 0 & 0 \\
& Total & 0 & 100 \\
& Posisi Saat Ini & 67 & 37 \\
& Senior & & 63 \\
Junior & 25 & 100 \\
& Total & 42 & 40
\end{tabular}




\begin{tabular}{ccc}
$1-2$ Tahun & 18 & 27 \\
$>2$ Tahun & 22 & 33 \\
Total & 67 & 100 \\
\hline
\end{tabular}

Sumber: Data diolah, 2018

Hasil yang disampaikan pada Tabel 3 menunjukkan bahwa total responden sebanyak 67 orang hampir seimbang antara pria dan wanita. Total responden sebanyak 67 orang tersebut didominasi oleh pendidikan terakhir yaitu S1 dan didominasi oleh posisi saat ini yaitu junior. Total responden sebanyak 67 orang ini juga dilihat dari lamanya bekerja sebagai auditor lebih banyak yang bekerja selama 1 tahun.

Penelitian ini menggunakan uji validitas dan uji reliabilitas dalam pengujian instrumen. Uji validitas digunakan untuk menguji apakah instrumen penelitian dapat dikatakan valid apabila mampu mengukur sah atau tidaknya suatu instrument dalam mengungkapkan data dari variabel yang akan diteliti secara tepat. Kemudian Instrumen akan dikatakan reliabel apabila memiliki nilai cronbach's alpha lebih dari 0,70 (Ghozali, 2016). Hasil uji validitas dan reliabilitas dalam penelitian ini dapat dilihat pada Tabel 4 sebagai berikut:

Tabel 4.

Hasil Uji Validitas

\begin{tabular}{ccccc}
\hline Variabel & Indikator & $\begin{array}{c}\text { Koefisien } \\
\text { Korelasi }\end{array}$ & $\begin{array}{c}\text { Cronbach's } \\
\text { Alpha }\end{array}$ & Keterangan \\
\hline & $\mathrm{X}_{1.1}$ & .543 & & Valid dan reliabel \\
& $\mathrm{X}_{1.2}$ & .515 & & Valid dan reliabel \\
$\mathrm{X}_{1.3}$ & .747 & 0,792 & Valid dan reliabel \\
$\mathrm{X}_{1}$ & $\mathrm{X}_{1.4}$ & .651 & & Valid dan reliabel \\
& $\mathrm{X}_{1.5}$ & .622 & & Valid dan reliabel \\
& $\mathrm{X}_{1.6}$ & .647 & & Valid dan reliabel \\
& $\mathrm{X}_{1.7}$ & .566 & & Valid dan reliabel \\
& $\mathrm{X}_{2.1}$ & .597 & & Valid dan reliabel \\
& $\mathrm{X}_{2.2}$ & .698 & 0,831 & Valid dan reliabel \\
& $\mathrm{X}_{2.3}$ & .702 & & Valid dan reliabel \\
& $\mathrm{X}_{2.4}$ & .566 & & Valid dan reliabel \\
$\mathrm{X}_{2.5}$ & $\mathrm{X}_{2.6}$ & .691 & & Valid dan reliabel \\
& $\mathrm{X}_{2.7}$ & .648 & 0,738 & Valid dan reliabel \\
& $\mathrm{X}_{3.1}$ & .568 & & Valid dan reliabel \\
& $\mathrm{X}_{3}$ & & &
\end{tabular}




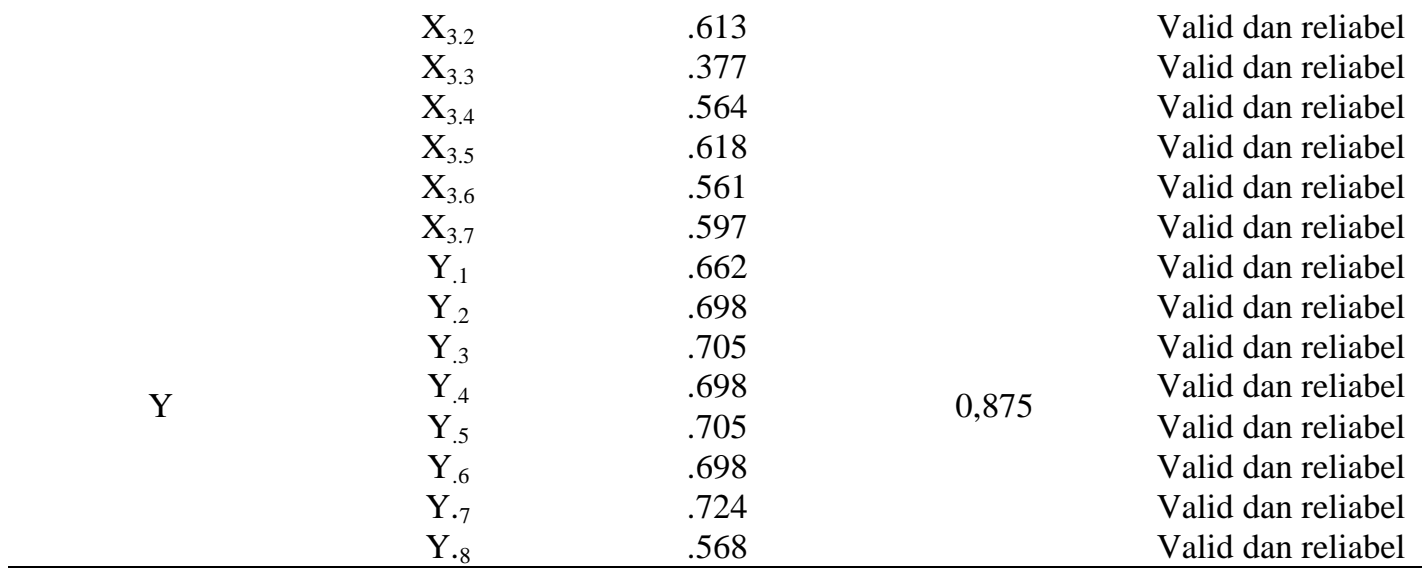

Sumber: Data diolah, 2018

Hasil yang disampaikan pada Tabel 4 menunjukkan bahwa seluruh instrumen penelitian berupa pernyataan-pernyataan pada kuesioner adalah valid karena nilai Corrected Item-Total Correlation lebih besar dari 0,3. Kemudian hasil juga menunjukkan bahwa seluruh instrumen penelitian berupa pernyataanpernyataan pada kuesioner adalah reliabel, yang berarti bahwa pernyataanpernyataan pada kuesioner dapat menunjukkan hasil yang konsisten walaupun dilakukan pengukuran kembali pada subjek yang sama pada waktu berbeda.

Model regresi yang baik yaitu model regresi yang didalamnya tidak terdapat masalah data yang distribusinya tidak normal, masalah multikolinieritas, dan masalah heteroskdastisitas. Oleh sebab itu sebelum dilakukan uji model regresi perlu dilakukan pengujian asumsi klasik terhadap model regresi yang akan digunakan terlebih dahulu. Apabila model regresi tidak lolos dalam pengujian ini maka model regresi tidak dapat digunakan. Berikut ini disajikan hasil uji asumsi klasik yang meliputi uji normalitas, uji multikolineiritas, dan uji heteroskedastisitas. Hasil uji normalitas dapat dilihat pada Tabel 5 berikut. 
Tabel 5.

Hasil Uji Normalitas

\begin{tabular}{lr}
\hline & Unstandardized Residual \\
\hline $\mathrm{N}$ & 67 \\
Kolmogorov Smirnov Z & 0,750 \\
Asymp. Sig (2-tailed) & 0,628 \\
\hline Sumber: Data diolah, 2018 &
\end{tabular}

Hasil uji pada Tabel 4.5 menunjukkan bahwa nilai asymp.sig (2-tailed) dari uji normalitas adalah sebesar 0,628 atau lebih besar dari $\alpha=0,05$. Hal ini menunjukkan bahwa model dalam penelitian ini berdistribusi normal. Sehingga dapat disimpulkan bahwa data yang digunakan dalam penelitian ini merupakan data yang berdistribusi dengan normal. Selanjutnya, hasil uji multikolinieritas data penelitian dapat dilihat pada Tabel 6 . Berdasarkan hasil uji multikolinieritas pada Tabel 6 maka dapat diketahui bahwa tidak ada variabel independen yang memiliki nilai tolerance sebesar $\leq 0,10$ atau nilai VIF $\geq 10$. Analisis ini menunjukkan bahwa tidak terdapat gejala multikolonieritas terhadap variabel penelitian.

Tabel 6.

Hasil Uji Multikolinieritas

\begin{tabular}{lcc}
\hline Variabel & Tolerance & VIF \\
\hline $\mathrm{X}_{1}$ & 0,125 & 7,977 \\
$\mathrm{X}_{2}$ & 0,201 & 4,971 \\
$\mathrm{X}_{3}$ & 0,179 & 5,582 \\
\hline
\end{tabular}

Sumber: Data diolah, 2018

Hasil uji heteroskedastisitas data penelitian ini bertujuan untuk mendeteksi ada atau tidaknya heteroskedastisitas dilakukan dengan melakukan uji glejser, apabila probabilitas signifikansinya diatas tingkat kepercayaan 5 persen maka dapat disimpulkan model regresi tidak mengandung heteroskedastisitas (Ghozali, 2016). Hasil uji heteroskedastisitas data penelitian ini dapat dilihat pada dapat dilihat pada Tabel 7. 
Tabel 7.

Hasil Uji Heteroskedastisitas

\begin{tabular}{lcc}
\hline Variabel & $\mathrm{t}$ & Sig. \\
\hline $\mathrm{X}_{1}$ & 1,738 & 0,087 \\
$\mathrm{X}_{2}$ & $-0,123$ & 0,903 \\
$\mathrm{X}_{3}$ & $-0,923$ & 0,359 \\
\hline Sumber: Data diolah, 2018 & &
\end{tabular}

Berdasarkan hasil uji heteroskedastisitas pada Tabel 7 maka dapat diketahui bahwa semua variabel independen memiliki nilai signifikansi $>5$ persen atau 0,05. Analisis ini menunjukkan bahwa model regresi tidak mengandung heteroskedastisitas. Hasil statistik deskriptif disajikan pada Tabel 4.8 berikut.

Tabel 8.

Hasil Statistik Deskriptif

\begin{tabular}{lccccc}
\hline & $\mathrm{N}$ & Min & Max & Mean & Std. Deviation \\
\hline $\mathrm{X}_{1}$ & 67 & 24,00 & 35,00 & 30,37 & 2,63 \\
$\mathrm{X}_{2}$ & 67 & 24,00 & 35,00 & 30,30 & 2,69 \\
$\mathrm{X}_{3}$ & 67 & 25,00 & 35,00 & 30,52 & 2,32 \\
$\mathrm{Y}$ & 67 & 27,00 & 40,00 & 35,00 & 3,31 \\
\hline
\end{tabular}

Sumber: Data diolah, 2018

Berdasarkan hasil stastistik deskriptif yang disajikan pada Tabel 8, nilai rata-rata profesionalisme $\left(X_{1}\right)$ adalah sebesar 30,37 hampir mendekati nilai maksimumnya yaitu 35,00 daripada nilai minimumnya yaitu 24,00 . Nilai ini menyatakan bahwa responden memberikan pendapat dengan skor mendekati maksimal yang mengindikasikan bahwa auditor pada KAP yang berada di Provinsi Bali tahun 2018 dominan menjawab sangat setuju pada pernyataan kuesioner bagian profesionalisme. Nilai standar deviasi profesionalisme $\left(\mathrm{X}_{2}\right)$ yaitu 2,63 yang memiliki nilai lebih kecil dari nilai rata-ratanya yaitu sebesar 30,37, ini berarti rentang jarak antara nilai maksimum dan nilai minimum tidak terlalu besar dan memiliki makna bahwa jawaban responden tidak terlalu berbeda dan memiliki jawaban yang relatif sama. 
Ni Putu Haris Candra Devi dan I Made Pande Dwiana Putra. Pengaruh ...

Nilai rata-rata independensi $\left(\mathrm{X}_{2}\right)$ adalah sebesar 30,30 hampir mendekati nilai maksimumnya yaitu 35,00 daripada nilai minimumnya yaitu 24,00. Nilai ini menyatakan bahwa responden memberikan pendapat dengan skor mendekati maksimal yang mengindikasikan bahwa auditor pada KAP yang berada di Provinsi Bali tahun 2018 dominan menjawab sangat setuju pada pernyataan kuesioner bagian independensi. Nilai standar deviasi independensi $\left(\mathrm{X}_{2}\right)$ yaitu 2,69 yang memiliki nilai lebih kecil dari nilai rata-ratanya yaitu sebesar 30,30 ini berarti rentang jarak antara nilai maksimum dan nilai minimum tidak terlalu besar dan memiliki makna bahwa jawaban responden tidak terlalu berbeda dan memiliki jawaban yang relatif sama.

Nilai rata-rata pelatihan auditor $\left(\mathrm{X}_{3}\right)$ adalah sebesar 30,52 hampir mendekati nilai maksimumnya yaitu 35,00 daripada nilai minimumnya yaitu 25,00. Nilai ini menyatakan bahwa responden memberikan pendapat dengan skor mendekati maksimal yang mengindikasikan bahwa auditor pada KAP yang berada di Provinsi Bali tahun 2018 dominan menjawab sangat setuju pada pernyataan kuesioner bagian pelatihan auditor. Nilai standar deviasi pelatihan auditor $\left(\mathrm{X}_{3}\right)$ yaitu 2,32 yang memiliki nilai lebih kecil dari nilai rata-ratanya yaitu sebesar 30,52 ini berarti rentang jarak antara nilai maksimum dan nilai minimum tidak terlalu besar dan memiliki makna bahwa jawaban responden tidak terlalu berbeda dan memiliki jawaban yang relatif sama.

Nilai rata-rata kinerja auditor (Y) adalah sebesar 35,00 hampir mendekati nilai maksimumnya yaitu 40,00 daripada nilai minimumnya yaitu 27,00 . Nilai ini menyatakan bahwa responden memberikan pendapat dengan skor mendekati 
maksimal yang mengindikasikan bahwa auditor pada KAP yang berada di Provinsi Bali tahun 2018 dominan menjawab sangat setuju pada pernyataan kuesioner bagian kinerja auditor. Nilai standar deviasi kinerja auditor (Y) yaitu 3,31 yang memiliki nilai lebih kecil dari nilai rata-ratanya yaitu sebesar 35,00, ini berarti rentang jarak antara nilai maksimum dan nilai minimum tidak terlalu besar dan memiliki makna bahwa jawaban responden tidak terlalu berbeda dan memiliki jawaban yang relatif sama.

Teknik analisis data yang digunakan untuk mengetahui pengaruh Profesionalisme $\left(\mathrm{X}_{1}\right)$, Independensi $\left(\mathrm{X}_{2}\right)$, dan Pelatihan Auditor $\left(\mathrm{X}_{3}\right)$ terhadap Kinerja Auditor (Y), dalam penelitian ini menggunakan analisis regresi linear berganda. Hasil dari analisis tersebut dapat dilihat dari Tabel 9 berikut.

Tabel 9.

Hasil Analisis Regresi Linear Berganda

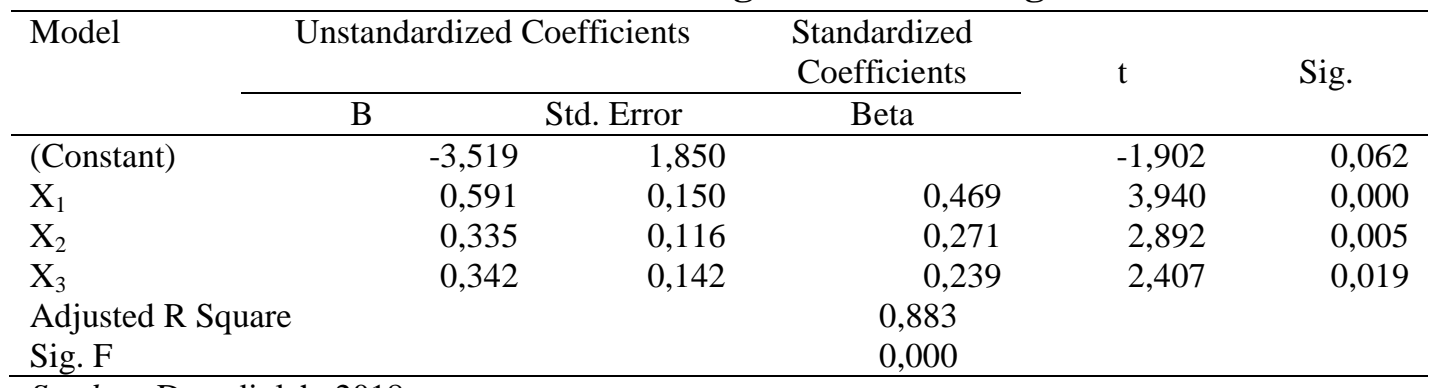

Sumber: Data diolah, 2018

Pada Tabel 9 dapat dibentuk model regresi linear berganda yaitu sebagai berikut.

$$
Y=-3,519+0,591 X_{1}+0,335 X_{2}+0,342 X_{3}
$$

Berdasarkan persamaan 2 dapat diketahui bahwa nilai konstanta $(\alpha)$ menunjukkan nilai -3,519 maka memiliki arti bahwa jika profesionalisme, independensi dan pelatihan auditor dinyatakan konstan pada angka 0 , maka 
Ni Putu Haris Candra Devi dan I Made Pande Dwiana Putra. Pengaruh ...

kinerja auditor adalah sebesar -3,519. Pada persamaan 2 juga terlihat bawa terdapat pengaruh positif profesionalisme $\left(\mathrm{X}_{1}\right)$ pada kinerja auditor $(\mathrm{Y})$ yaitu sebesar 0,591. Terdapat pengaruh positif independensi $\left(\mathrm{X}_{2}\right)$ pada kinerja auditor (Y) yaitu sebesar 0,335 . Pelatihan auditor $\left(\mathrm{X}_{3}\right)$ pada kinerja auditor $(\mathrm{Y})$ yaitu sebesar 0,342 .

Hasil analisis regresi linear berganda pada Tabel 9 menunjukkan bahwa nilai Adjusted $R$ Square adalah sebesar 0,883. Hal ini menunjukkan bahwa $88,30 \%$ variasi kinerja auditor mampu dijelaskan oleh profesionalisme, independensi, dan pelatihan auditor, sedangkan sisanya $(100 \%-88,30 \%=$ $11,70 \%$ ) variasi kinerja auditor dijelaskan oleh faktor-faktor lain yang tidak dijelaskan dalam model. Kemudian hasil uji F dalam Tabel 9 menunjukkan nilai signifikansi $\mathrm{F}$ adalah sebesar $0,000<0,05$. Hal ini menunjukkan bahwa model regresi ini layak atau profesionalisme, independensi dan pelatihan auditor mampu menjelaskan kinerja auditor.

Tabel 9 menunjukkan bahwa profesionalisme berpengaruh terhadap kinerja auditor. Nilai beta $=0,591$, ini menunjukkan hubungan yang positif antara profesionalisme dengan kinerja auditor. Maka hipotes pertama $\left(\mathrm{H}_{1}\right)$ diterima, yaitu profesionalisme berpengaruh positif terhadap kinerja auditor. Sesuai dengan teori kinerja, faktor individu auditor yaitu profesionalisme dapat memengaruhi kinerja auditor tersebut. Seorang auditor yang profesional memiliki ciri-ciri seperti cermat dalam mengerjakan tugas, dan tidak menggabungkan urusan pekerjaan dengan urusan pribadi. Ini berarti auditor dalam mengerjakan tugasnya akan cermat dan menghindari kelalaian dan tentunya tidak terpengaruh oleh masalah pribadi karena 
hasil audit auditor tersebut akan dipublikasikan kepada masyarakat. Sesuai dengan teori keagenan, maka profesionalisme akan meyakikan pendapat auditor atas kewajaran laporan keuangan.

Jika auditor tidak dapat professional, maka kinerja auditor tersebut akan tidak baik dan didukung dengan menghilangnya kepercayaan pihak ketiga dan timbulnya keraguan atas kinerja auditor tersebut. Oleh sebab itu penting bagi auditor untuk menjaga sikap profesionalnya agar kinerjanya baik dan dinilai bagus oleh pihak ketiga. Hasil penelitian ini memperkuat hasil penelitian Bamber dan Iyer (2002), Cohen dan Single (2001), Dinata (2013) dan Adhi (2015) yang menunjukkan bahwa profesionalisme berpengaruh positif terhadap kinerja auditor.

Tabel 9 menunjukkan bahwa independensi berpengaruh terhadap kinerja auditor. Nilai beta $=0,335$, ini menunjukkan hubungan yang positif antara independensi dengan kinerja auditor. Maka hipotesis kedua $\left(\mathrm{H}_{2}\right)$ diterima, yaitu independensi berpengaruh positif terhadap kinerja auditor. Sesuai dengan teori kinerja, faktor individu kedua auditor yaitu independensi juga dapat memengaruhi kinerja auditor. Saat auditor bersikap independen, baik independen dalam pemikirannya dan independen dalam penampilannya, memungkinkan auditor tersebut untuk bekerja dengan penuh integritas, bertindak objektif serta dapat meyakinkan pihak ketiga bahwa auditor tersebut kinerjanya baik dan public yakin terhadap pendapat auditor atas kewajaran pada laporan keuangan.

Hasil penelitian ini memperkuat hasil penelitian yang dilakukan Gabritha (2014) yang menyatakan bahwa independensi berpengaruh signifikan terhadap kinerja auditor pada Kantor Akuntan Publik di Jakarta dan Dinata (2013) dalam 
penelitiannya di Kantor Akuntan Publik di Bali. Ini berarti semakin tinggi tingkat independensi auditor maka kinerja yang dihasilkannya pun semakin tinggi juga.

Tabel 9 menunjukkan bahwa pelatihan auditor berpengaruh terhadap kinerja auditor. Nilai beta $=0,342$, ini menunjukkan hubungan yang positif antara pelatihan auditor dengan kinerja auditor. Maka hipotesis ketiga $\left(\mathrm{H}_{3}\right)$ diterima, yaitu pelatihan auditor berpengaruh positif terhadap kinerja auditor. Sesuai dengan teori kinerja, faktor dukungan organisasional berupa pelatihan auditor juga dapat memengaruhi kinerja auditor. Seringnya seorang auditor mengkuti pelatihan akan menambah ilmu auditor tersebut, dan ilmu tersebut bisa digunakan secara maksimal, sehingga meningkatan kinerja auditor tersebut secara signifikan dan menghasilkan pendapat yang baik atas kewajaran laporan keuangan.

Hasil penelitian ini mendukung hasil penelitian Jamilah (2008) dalam penelitiannya di Inspektorat Provinsi Sumatera Utara menyatakan terdapat pengaruh yang positif dari pelatihan terhadap kinerja auditor dan penelitian yang dilakukan Adinda (2014) menunjukkan bahwa variabel pelatihan berpengaruh secara signifikan terhadap kinerja auditor junior, serta penelitian yang dilakukan oleh Adhi (2015).

Hasil penelitian ini dapat memberikan informasi, wawasan, dan referensi serta memberikan pemahaman dan gambaran yang lebih mendalam mengenai bagaimana pengaruh profesionalisme, independensi dan pelatihan auditor terhadap kinerja auditor. Terdapat bukti empiris yang diperoleh melalui penelitian ini yaitu profesionalisme, independensi dan pelatihan auditor berpengaruh positif terhadap kinerja auditor yang ada di Provinsi Bali tahun 2018. Hal ini berarti 
semakin meningkatnya profesionalisme, independensi dan pelatihan pada auditor maka semakin meningkat pula kinerja auditor tersebut.

Penelitian ini dapat memberikan referensi tambahan kepada organisasi/instansi, apakah profesionalisme, independensi dan pelatihan auditor berpengaruh terhadap kinerja auditor. Pemahaman ini juga diharapkan dapat membantu organisasi/instansi mengetahui apakah profesionalisme, independensi dan pelatihan auditor berpengaruh terhadap kinerja auditor. Penelitian ini juga memberikan deskripsi tentang pengaruh profesionalisme, independensi, dan pelatihan auditor terhadap kinerja auditor yang dapat dijadikan acuan untuk penelitian selanjutnya.

\section{SIMPULAN}

Berdasarkan hasil pengujian dan pembahasan dari pengaruh profesionalisme, independensi dan pelatihan auditor terhadap kinerja auditor, maka dapat disimpulkan bahwa profesionalisme berpengaruh positif dan signifikan terhadap kinerja auditor, independensi berpengaruh positif dan signifikan terhadap kinerja auditor, dan pelatihan auditor berpengaruh positif signifikan terhadap kinerja auditor.

Penelitian ini diharapkan dapat digunakan sebagai bahan pertimbangan oleh auditor agar dalam melakukan audit, menjunjung tinggi profesionalisme dan independensinya serta perlu mengikuti pelatihan sehingga auditor yang bersangkutan dapat meningkatkan kinerjanya. 
Ni Putu Haris Candra Devi dan I Made Pande Dwiana Putra. Pengaruh ...

Hasil koefisien determinasi $\left(\mathrm{R}^{2}\right)$ adalah $88,30 \%$. Ini berarti masih ada variabel bebas lain yang dapat memengaruhi kinerja auditor. Penelitian selanjutnya dapat menambahkan variabel bebas lain diluar penelitian ini dan juga menambahkan KAP yang berbeda dengan penelitian ini.

\section{REFERENSI}

Adhi, N. I. B. (2015). Pengaruh Profesionalisme, Etika Profesi dan Pelatihan Auditor Terhadap Kinerja Auditor pada Kantor Akuntan Publik di Bali. Jurnal Fakultas Ekonomi Universitas Udayana.

Adinda, Y. (2014). Pengaruh Motivasi, Supervisi dan Pelatihan Terhadap kinerja Auditor Junior. Skripsi Universitas Islam Negeri Syarif Hidayatullah.

Agustina, S. D. (2006). Hubungan Sikap dan Lingkungan Internal Dengan Prestasi Kerja Karyawan Perusahaan Daerah Air Minum Kota Surakarta. Lembaga Penelitian Universitas Muhamadiyah Surakarta.

Arens, A. and Beasley. (2008). Auditing and Asurance Service an Integrated Appoach. $13^{\text {th }}$ edition. Global edition. New Jersey: Pearson Education Internasional.

Ariani, W. A. A. (2015). Pengaruh Profesionalisme, Etika Profesi, Tingkat Pendidikan dan Pengalaman Kerja pada Kinerja Auditor Inspektorat Provinsi Bali. Tesis. Fakultas Ekonomi Universitas Udayana.

Arifin. (2007). Peran Akuntan Dalam Menegakkan Prinsip Good Corporate Governance pada Perusahaan di Indonesia (Tinjauan Perspektif Teori Keagenan). Usulan Jabatan Guru Besar. Fakultas Ekonomi Universitas Diponegoro.

Astika, P. I. B. (2011). Teori Akuntansi: Konsep Dasar Akuntansi Keuangan. Fakultas Ekonomi Universitas Udayana.

Bahri, S. (2010). Pengaruh Gaya Kepemimpinan dan Komitmen Organisasi Terhadap Kinerja Auditor Junior. Skripsi UIN.

Bamber, M., and Iyer, V. (2002). Big 5 Auditor's Profesional and Organizational Identiffication: Consistency or Conflict. A Journal Practice \& Theory, 20(2), 21. 
Bandar, W. P. G. (2012). Pengaruh Independensi, Profesionalisme, Struktur Audit dan Role Stress Terhadap Kinerja Auditor BPK RI Perwakilan Provinsi Bali. Jurnal. Fakultas Ekonomi Universitas Udayana.

Bonner, S. E. (1994). Experience Effects in Auditing: The Role of Task-Spesific.

Boyton, W. and Johnson. (2006). Modern Auditing. New Jersey: John Willey \& Sons, Inc.

Cathy dan Christine. (2011). Responsible Leadership for Audit Quality, How dothe Big Four Manage The Personal Ethics Of their Employees? Journal Audencia Nantes School of Management.

Chandra, F. K. (2006). Pengaruh Tindakan Supervisi Terhadap Kinerja Auditor Internal dengan Motivasi Kerja sebagai Variabel Interening. Skripsi Universitas Diponogoro Semarang.

Cholifah, W. R. (2010). Pengaruh Supervisi dan Pelatihan Terhadap Kinerja Auditor Junior. Skirpsi UIN.

Cohen, J., and Single, L. (2001). Responsible Leadership for Audit Quality, How dothe Big Four Manage The Personal Ethics Of their Employees? Journal Audencia Nantes School of Management.

Curtis, M., Teresa, C., and Lawrence, C. (2012). A Cross-Cultural Study of the Influence of Country of Origin, Justice, Power Distance, adn Gender on Etical Decision Making. Journal Of Internasional Accounting Research, 11(1), 5-34.

Danielle, E. W. dan Miguel, A. (2008). Ensuring Independent Auditor: Increasing the Saliency of the Profesional Identity. Journal. United States of America.

Dian, A. (2011). The Influence Of Auditor's Profesionalism to Turnover Itentions, An Empirical Study on Accounting Frm in Java and Bali, Indonesia. Jurnal of Economics and Engineering, 2(1).

Dinata, P. K. M. (2013). Pengaruh Indepedensi, Profesionalisme, dan Etika Profesi Terhadap Kinerja Auditor Pada Kantor Akuntan Publik di Bali. Jurnal Fakultas Ekonomi Universitas Udayana.

Eka, P. (2012). Pengaruh Kompetensi. Tekanan Waktu, Pengalaman Kerja, Etika dan Independensi Auditor terhadap Kualitas Audit. Skripsi. UNY.

Eynon, G., Hills, N. T., and Stevens, K. T. (1997). Factors that Influence the Moral reasoning Abilities of Accountans: Implications for Universities and the Profession. Journal of Business Ethics. 
Fahari, Z. (2008). Pengaruh Struktur Audit, Konflik Peran, dan Ketidakjelasan Peran Tehadap Kinerja Auditor. Jurnal Akutansi dan Keuangan Indonesia. Jakarta.

Futri, P. S. dan Juliarsa, G. (2014). Pengaruh Independensi, Profesionalisme, Tingkat Pendidikan, Etika Profesi, Pengalaman, dan Kepuasan Kerja Auditor pada Kualitas Audit Kantor Akuntan Publik di Bali. E-Jurnal Akuntansi Universitas Udayana, 7(2), 444-461.

Gabritha, F. (2014). engaruh Kecerdasan Emosional, Kecerdasan Spiritual, dan Etika Profesi terhadap Kinerja Auditor Pada Kantor Akuntan Publik di Jakarta. Jurnal Universitas Binus Jakarta.

Ghozali, I. (2016). Aplikasi Analisis Multivariete dengan Program IBM SPSS 23 (8th ed.). Semarang: Undip.

Harahap, G. S. (2011). Pengaruh Pengetahuan Audit dan Pengalaman Audit terhadap Peningkatan Keahlian Auditor dalam Bidang Auditing pada Kantor Akuntan Publik (KAP) di Pekanbaru. Skripsi. Fakultas Ekonomi dan Ilmu Sosial Universitas Islam Negeri Sultan Syarif Kasim Riau.

Hartono, Y. (2014). Auditing (Pengauditan Berbasis ISA). Edisi 2. Yogyakarta: Bagian Penerbitan Sekolah Tinggi Ilmu Ekonomi YKPN.

Herliansyah, Y. (2008). Pengaruh Pengalaman Auditor Terhadap Penggunaan Bukti Tidak Relevan Dalam Auditor Judgement. Jurnal. Fakultas Ekonomi Universitas Mercu Buana.

Ikatan Akuntan Indonesia. (2004). Standar Profesional Akuntan Publik. Jakarta: Salemba Empat.

Jamilah, L. L. (2008). Pengaruh Pelatihan Jabatan Fungsional Auditor (JFA) Terhadap Kinerja Auditor pada Inspektorat Provinsi Sumatera Utara. Jurnal Fakultas Ekonomi Universitas Sumatera Utara.

Kalbers, L. P. dan Fogarty, T. J. (1995). Profesionalism its consequences: a study of internal auditors. Auditing A journal of Practice, 14(1), 64-68.

Mahsun, M., Firma, S., dan Heribertus, A. P. (2007). Akutansi Sektor Publik. Yogyakarta: BPFE.

Marianus, S. (2008). Teori Akutansi. Edisi ke Empat Jilid Satu. Jakarta: Erlangga.

Mangkunegara, A. P. (2005). Evaluasi Kinerja SDM. Bandung: Refika Aditama. Mulyadi. (2009). Auditing. Edisi ke-6. Buku 1. Jakarta: Salemba Empat. 
Mulyadi dan Kanaka, P. (1998). Auditing Pendekatan Terpadu. Jakarta: Salemba Empat.

Munawir, H. S. (2008). Auditing Modern. Yogyakarta: BPFE.

Noviyani, P., dan Bandi. (2002). Pengaruh Pengalaman dan Pelatihan terhadap Struktur Pengetahuan Auditor Tentang Kekeliruan. Simposium Nasional Akuntansi $V$.

Pebi, N. N. (2010). Pengaruh Struktur Audit, Komitmen Organisasi, Gaya Kepemimpinan, dan Pemahaman God Governance pada Kinerja Auditor (Studi Empiris pada Kantor Akuntan Publik di Bali). Skripsi. Fakultas Ekonomi Universitas Udayana.

Ria, N., Diani, M., and Rita, A. (2010). A study On Audit Judgement Performance: The Effect of Accountabillity, Effort, and Task Complexity. Jurnal. University of Riau.

Riyadi, S. (2011). Pengaruh Kompensasi Finansial, Gaya Kepemimpinan, dan Motivasi Kerja Terhadap Kinerja Karyawan pada Perusahaan Manufaktur di Jawa Timur. Jurnal Manajemen Dan Kewirausahaan, 40-45.

Sukrisno, A. (2004). Auditing (Pemeriksaan Akuntan) Oleh Kantor Akuntan Publik. Jilid I. Edisi Ketiga. Jakarta: Lembaga Penerbit Fakultas Ekonomi Universitas Udayana.

Sugiyono. (2011). Metode Penelitian Bisnis. Bandung: Alfabeta.

Surya, A. I. A. (2007). Pengaruh Fee Audit, Ukuran Kantor Akuntan Publik dan Lamanya Penigasan Audit Terhadap Independensi Penampilan Auditor. Jurnal. Fakultas Ekonomi Universitas Udayana.

Suseno, N. S. (2013). Literature Review The Effect of Independence, Size of Public Accountant Office Toward Audit Quality and Its Impact on Public Accountant Reputation. Journal of Applied Science Researches, 9(1), 62-66.

Susiana dan Arleen, H. (2009). Analisis Pengaruh Independensi, Mekanisme Corporate Governance, dan Kualitas Audit Terhadap Integritas Laporan Keuangan. Simposium Nasional Akuntansi X. Makassar.

Trianingsih, S. (2007). Independensi Auditor Dan Komitmen Organisasi Sebagai Mediasi Pengaruh Pemahaman Good Governance, Gaya Kepemimpinan Dan Budaya Organisasi Terhadap Kinerja Auditor. Jurnal Akuntansi, 2(2), 1-56.

Utama, S. (2009). Aplikasi Analisis Kuantitatif. Bali: Fakultas Ekonomi Universitas Udayana. 
Ni Putu Haris Candra Devi dan I Made Pande Dwiana Putra. Pengaruh ...

Winarna, J. (2005). Independensi Auditor: Suatu Tantangan Di Masa Depan. Jurnal Akuntansi, 5(2), 178-186.

Wibowo, H. A. O. (2009). Pengaruh Independensi Auditr, Komitmen Organisasi, Gaya Kepemimpinan, dan Pemahaman Good Governance Terhadap Kinerja Auditor (Studi emiris pada Kantor Akuntan publik di Daerah Istimewa Yogyakarta). Skripsi. Fakultas Ekonomi Universitas Islam Indonesia.

Yanhari. (2007). Analisis Profesionalisme dan Etika Profesi Auditor terhadap Kinerja Auditor (Studi kasus pada Badan Pemeriksa Keuangan RI di Jakarta). Skripsi Fakultas Ekonomi Mercubuana. 